Article

\title{
An Archaeosome-Adjuvanted Vaccine and Checkpoint Inhibitor Therapy Combination Significantly Enhances Protection from Murine Melanoma
}

\author{
Felicity C. Stark, Risini D. Weeratna, Lise Deschatelets, Komal Gurnani, Renu Dudani, \\ Michael J. McCluskie (D) and Lakshmi Krishnan* \\ National Research Council of Canada-Human Health Therapeutics, 1200 Montreal Rd., Ottawa, ON K1A 0R6, \\ Canada; Felicity.Stark@nrc-cnrc.gc.ca (F.C.S.); risini.weeratna@nrc-cnrc.gc.ca (R.D.W.); \\ Lise.Deschatelets@nrc-cnrc.gc.ca (L.D.); Komal.Gurnani@nrc-cnrc.gc.ca (K.G.); \\ Renu.Dudani@nrc-cnrc.gc.ca (R.D.); Michael.McCluskie@nrc-cnrc.gc.ca (M.J.M.) \\ * Correspondence: Lakshmi.Krishnan@nrc-cnrc.gc.ca; Tel.: +1-613-991-3210
}

Academic Editor: Olga Borges

Received: 16 September 2017; Accepted: 20 October 2017; Published: 26 October 2017

\begin{abstract}
Archaeosomes constitute archaeal lipid vesicle vaccine adjuvants that evoke a strong $\mathrm{CD}^{+} \mathrm{T}$ cell response to antigenic cargo. Therapeutic treatment of murine B16-ovalbumin (B16-OVA) melanoma with archaeosome-OVA eliminates small subcutaneous solid tumors; however, they eventually resurge despite an increased frequency of circulating and tumor infiltrating OVA-CD8 ${ }^{+} \mathrm{T}$ cells. Herein, a number of different approaches were evaluated to improve responses, including dose number, interval, and the combination of vaccine with checkpoint inhibitors. Firstly, we found that tumor protection could not be enhanced by repetitive and/or delayed boosting to maximize the $\mathrm{CD} 8^{+} \mathrm{T}$ cell number and/or phenotype. The in vivo cytotoxicity of vaccine-induced $\mathrm{OVA}^{-\mathrm{CD} 8}{ }^{+} \mathrm{T}$ cells was impaired in tumor-bearing mice. Additionally, tumor-infiltrating OVA-CD8 ${ }^{+}$ $\mathrm{T}$ cells had an increased expression of programmed cell death protein-1 (PD-1) compared to other organ compartments, suggesting impaired function. Combination therapy of tumor-bearing mice with the vaccine archaeosome-OVA, and $\alpha$-CTLA- 4 administered concurrently as well as $\alpha$-PD- 1 and an $\alpha$-PD-L1 antibody administered starting 9 days after tumor challenge given on a Q3Dx4 schedule (days 9, 12, 15 and 18), significantly enhanced survival. Following multi-combination therapy $\sim 70 \%$ of mice had rapid tumor recession, with no detectable tumor mass after $>80$ days in comparison to a median survival of 17-22 days for untreated or experimental groups receiving single therapies. Overall, archaeosomes offer a powerful platform for delivering cancer antigens when used in combination with checkpoint inhibitor immunotherapies.
\end{abstract}

Keywords: checkpoint inhibitor; PD-1; PD-L1; CTLA-4; tumor-infiltrating lymphocyte (TIL); cancer vaccine; $\mathrm{CD} 8^{+} \mathrm{T}$ cell response; archaeosome; prime-boost; B16; liposome; tumor vaccine; effector $\mathrm{T}$ cell (TE); effector memory T cell (TEM)

\section{Introduction}

Metastatic melanoma is a deadly form of cancer due to its highly invasive nature and limited treatment options. While localized non-melanoma skin cancers can be easily cured by surgical removal with little risk of relapse, unresectable stage IV metastatic melanoma has a 5-year survival rate of less than 5\% [1]. Most recently, checkpoint inhibitor immunotherapy to augment $\mathrm{T}$ cell responses has been approved as a first-line standard of care treatment for metastatic melanoma; this has drastically improved patient survival. Two recent clinical trials for untreated melanoma using 
a combination of nivolumab ( $\alpha$-programmed cell death protein-1, $\alpha$-PD-1) and ipilimumab ( $\alpha$-CTLA-4) reported objective response rates of $53 \%$ and $61 \%$, with complete responses seen in $11.5 \%$ and $22 \%$ of patients [2,3]. To put this in perspective, until recently dacarbazine was the treatment of choice for metastatic melanoma with a 2-year survival rate for patients (with normal LDH levels) of only 40\% [4]; however, the inclusion of checkpoint inhibitors nivolumab ( $\alpha$-PD-1) and ipilimumab ( $\alpha$-CTLA-4) has doubled the 1- and 2-year survival rates to $85 \%$ and $79 \%$, respectively, [5-7] thus marking a sharp turn in cancer therapeutics for melanoma and sparking multiple new clinical trials with checkpoint inhibitor therapy for other cancers [8-11]. While some cancers are immunogenic enough to sustain anti-tumor $\mathrm{CD}^{+} \mathrm{T}$ cell responses in the tumor and periphery, one of the barriers to success with checkpoint inhibitor therapy is thought to be the absence of anti-tumor $\mathrm{T}$ cells to non-immunogenic tumors. Since checkpoint inhibitors primarily act on T cells by "removing the breaks" that prevent their full function, patients without sufficient tumor-specific $\mathrm{CD}^{+}$and $\mathrm{CD}^{+} \mathrm{T}$ cells would be unable to benefit from most checkpoint inhibitor therapies. As a result, there is a renewed interest in cancer vaccines that can stimulate potent $\mathrm{CD}^{+} \mathrm{T}$ cell responses.

Archaeosomes have been shown to activate antigen-specific $\mathrm{CD}^{+} \mathrm{T}$ cell responses in multiple pre-clinical studies to date [12]. They exhibit high stability and can not only deliver antigen to antigen presenting cells (APCs) but also possess strong adjuvant properties leading to the induction of potent and long-lasting antigen-specific humoral and cell-mediated immune responses $[13,14]$. Archaeosomes are liposome vesicles that are composed of glycero-lipids derived from Archaebacteria. Archaeal lipids differ from conventional eubacteria lipids as they possess phytanyl, fully-saturated core lipids, ether linked to the glycerol back-bone. Archaeosomes have traditionally been composed of total polar lipids (TPLs) extracted from archaea and while many different archaebacteria lipids have been tested to formulate archaeosomes, Methanobrevibacter smithii was selected for this study as its lipid composition was found to be optimal for eliciting CD8 ${ }^{+} \mathrm{T}$ cell effector and memory responses when compared to other TPL archaeosomes [13,14]. Archaeosomes can also break tolerance to self-antigens [15], and since they themselves are non-immunogenic they are also highly suitable for homologous prime-boost vaccinations, generating high levels $(\sim 45 \%)$ of tumor-protective antigen-specific $\mathrm{CD}^{+} \mathrm{T}$ cells [16]. However, it has been shown that despite the generation of a large number of tumor-specific effector $\mathrm{CD}^{+} \mathrm{T}$ cells, tumor progression can still recur [17-19]; this is in part due to tumor-induced immunosuppression that can dampen the cytotoxicity of $\mathrm{CD}^{+} \mathrm{T}$ cells [20]. Therefore, many of the current immunotherapeutic strategies aim to not only activate antigen-specific $\mathrm{T}$ cells but also to inhibit regulatory receptors with checkpoint inhibitors such as $\alpha \mathrm{PD}-1, \alpha \mathrm{PD}-\mathrm{L} 1$ and/or $\alpha$ CTLA-4.

In this therapeutic B16-ovalbumin (B16-OVA) solid tumor melanoma mouse model study, ovalbumin was entrapped within archaeosomes composed of TPLs derived from M. smithii (MS-OVA archaeosomes) and delivered therapeutically to B16-OVA solid tumor-bearing C57BL/6 mice. The responding $\mathrm{CD}^{+} \mathrm{T}$ cell response and phenotype were monitored in the blood and organ compartments. Tumor survival was monitored in a therapeutic MS-OVA archaeosome setting with or without the addition of the checkpoint inhibitors $\alpha$ PD-1, $\alpha$ PD-L1, and/or $\alpha$ CTLA- 4 . The usefulness of archaeosomes in combination with checkpoint inhibitors to act synergistically providing long-term protection against solid B16-OVA tumors is presented.

\section{Materials and Methods}

\subsection{Vaccine Delivery Systems and Route of Immunization}

Archaeosomes were prepared from the TPLs of M. smithii as described previously [21]. Briefly, the model protein OVA, type VI (Sigma-Aldrich, Oakville, ON, Canada) was encapsulated within archaeosomes by hydrating dried TPLs. Vesicle diameter was reduced to $100 \mathrm{~nm}$ by sonication and assessed with a particle sizer (Nicomp 350, Santa Barbara, CA, USA). Non-entrapped OVA was removed from solution by ultracentrifugation at $327,000 \times g$. The supernatant was discarded and the 
pellet was re-suspended in 1-2 $\mathrm{mL}$ of water by gentle vortexing and filtered manually through a $0.45-\mu \mathrm{m}, 25-\mathrm{mm}$-diameter syringe-driven sterilizing filter. Encapsulated OVA was quantified by SDS-PAGE and the antigen: the lipid ratio was found to be in the range of $20 \mu \mathrm{g}$ OVA in $0.3-0.7 \mathrm{mg}$ of archaeal lipids. Working stocks for vaccines were diluted in phosphate-buffered saline (PBS; Thermo Fisher Scientific, Ottawa, ON, Canada) $(20 \mu \mathrm{g}$ OVA $/ 100 \mu \mathrm{L}$ PBS). Mice received a subcutaneous (s.c.) injection of MS-OVA (20 $\mu$ g OVA entrapped in archaeosomes) at the base of the tail at various time-points after tumor challenge (see Section 2.3 below). Numbers of animals per group and vaccination regimen are indicated in the figure legends.

\subsection{Mouse Strains and Adoptive Cell Transfer}

Here, 6-8 week old female C57BL/ 6 and OT.1 TCR transgenic mice (with CD8 ${ }^{+}$cells expressing the OVA $257-264$ TCR) were obtained from Jackson Laboratory (Bar Harbor, ME, USA). Mice were maintained at the small animal facility of the National Research Council Canada (NRC) in accordance with the guidelines of the Canadian Council on Animal Care. All animal use protocols were approved by the NRC Animal Care Committee (Protocol 2011.24). For results shown in Figures 4 and 5, mice received an adoptive transfer of $10^{5}$ OT.1 splenocytes 2 days after B16-OVA tumor injection to increase the frequency of circulating $\mathrm{OVA}-\mathrm{CD} 8^{+} \mathrm{T}$ cells as previously described [22].

\subsection{Tumor Model (B16-OVA, Melanoma)}

B16F0-OVA (expressing plasmid-derived full-length OVA) cells were obtained from Dr. Edith Lord (University of Rochester, Rochester, New York) and cultured as described previously [23,24]. Solid tumors were induced with s.c. injection of $1 \times 10^{6}$ B16-OVA cells. From day 5 onwards, a detectable solid tumor was measured using Digimatic Digital calipers (Mitutoyo 500-196, Aurora, IL, USA). Tumor size, expressed in $\mathrm{mm}^{2}$, was obtained by multiplication of diametrically perpendicular measurements. Animals were monitored for long-term survival. However, in order to minimize pain and discomfort, mice were euthanized when tumors reached $300 \mathrm{~mm}^{2}$.

\subsection{Assessment of In Vivo Cytolytic Activity}

In vivo cytolytic activity of $\mathrm{CD}^{+} \mathrm{T}$ cells was enumerated as described previously [25]. Briefly, a mixture of SIINFEKL peptide-pulsed and non-peptide-pulsed CFSE $(2 \mu \mathrm{M})$ labeled naive splenocytes was injected at a 1:1 ratio at different time points after MS-OVA administration in both tumor bearing or non-tumor bearing mice. At $24 \mathrm{~h}$ post cell injection, spleens were removed from recipient mice and analyzed by flow cytometry for loss of target cells relative to non-target control cells, and the percentage of in vivo killing was calculated.

\subsection{Detection of OVA-Specific CD8 ${ }^{+} T$ Cells}

At various time points (pre-vaccination, 1-week post-vaccination, and at regular intervals throughout the course of the study) blood (50-100 $\mu \mathrm{L})$ was collected via submandibular venipuncture for FACS analysis. At 33 and 37 days post tumor injection in MS-OVA treated mice blood, tumor, spleen, and lymph nodes were collected and processed for FACS analysis. Spleen and blood samples were processed as described previously [16]. Lymph nodes were processed by mashing between the frosted ends of two glass slides in RPMI 1640 medium (Invitrogen, Life Technologies, Grand Island, New York, NY, USA) supplemented with $8 \%$ fetal bovine serum (FBS) (HyClone Laboratories, Logan, UT, USA) (R8) and passed twice through a $45-\mu \mathrm{m}$ Falcon cell strainer. Cells were washed by centrifugation at $400 \times g$ for 8 min and finally re-suspended in $0.5 \mathrm{~mL}$ of $\mathrm{R} 8$ medium. Subcutaneous tumors were excised in R8 medium, cut into small pieces, and digested with sterile dissociation cocktail comprising a final concentration of $1 \mathrm{mg} / \mathrm{mL}$ of collagenase type 4 (Worthington Biochemical Corporation, Lakewood, NJ, USA), and $0.1 \mathrm{mg} / \mathrm{mL}$ of hyaluronidase (Sigma-Aldrich, Oakville, ON, Canada). Samples were incubated for $1 \mathrm{~h}$ in a $37^{\circ} \mathrm{C}$ shaking incubator, and then passed through a $45-\mu \mathrm{m}$ falcon cell strainer (BD Biosciences, 
Franklin Lakes, NJ, USA). Cells were centrifuged at $400 \times g$ for 8 min at RT and resuspended in $5 \mathrm{~mL}$ PBS $+1 \%$ BSA. Cells were strained and washed repeatedly until there were no visible clumps. Lymphocytes were isolated by Percoll ${ }^{\mathrm{TM}}$ density gradient centrifugation. Briefly, a gradient was prepared by successively layering $40 \%$ and $70 \%$ Percoll density solutions, and cells in PBS were layered on top. Samples were centrifuged at $800 \times \mathrm{g}$ for $25 \mathrm{~min}$ at $4{ }^{\circ} \mathrm{C}$. The lymphocytes were collected from the lower interphase, thoroughly washed in PBS, centrifuged, and resuspended in R8 medium. The low-density tumor cells were found concentrated in the upper interphase. Live cell number was enumerated by trypan blue exclusion using a hemocytometer. Single cell suspensions were first blocked with an anti-Fc receptor antibody $(\alpha-\mathrm{CD} 16)$ for $5 \mathrm{~min}$ at $4{ }^{\circ} \mathrm{C}$. Whole blood and single cell suspensions were stained with antibodies against CD8 ${ }^{+}$, IL-7R $\alpha, \mathrm{CD} 62 \mathrm{~L}$, and PD- 1 as well as with the MHC tetramer $\mathrm{H}-2 \mathrm{~K}^{\mathrm{b}} \mathrm{OVA}$. All antibodies were obtained from BD Biosciences (Mississauga, ON, Canada). The H-2K $\mathrm{K}^{\mathrm{b}} \mathrm{OVA}$-tetramer was obtained from Beckman Coulter (Mississauga, ON, Canada). Blood samples were treated with RBC lysing buffer (Sigma-Aldrich Oakville, ON, Canada) after antibody staining. Cells were washed with PBS, fixed with $0.5 \%$ paraformaldehyde, and acquired on a BD FACS Canto analyzer (Becton, Dickinson and Company, Franklin Lakes, NJ, USA). FSc vs. SSc gating was used to locate lymphocytes, exclude doublets, and exclude debris and dead cells. A further gate was set to identify $\mathrm{CD} 8^{+}$, and the MHC tetramer $\mathrm{H}-2 \mathrm{~K}^{\mathrm{b}} \mathrm{OVA}^{+}$cells. Single stained antibody controls were used to set compensation values between channels to prevent overlapping signals creating false-positives. Additionally, fluorescence minus one (FMO) gating controls were used. Flow cytometry data were analyzed using the FACS Diva ${ }^{\circledR}$ software (Becton, Dickinson and Company, Franklin Lakes, NJ, USA).

\subsection{Checkpoint Inhibitor Combination Therapy}

C57BL $/ 6$ mice were given $5 \times 10^{5}$ B16-OVA cells s.c. in the dorsal flank; 3, 8, and 18 days later $20 \mu \mathrm{g}$ MS-OVA was injected s.c. at the base of the tail away from the tumor site. A total of $100 \mu \mathrm{g} \alpha$-CTLA-4, Clone 9D9 (BioXcell, West Lebanon, NH, USA) was given s.c. alongside the archaeosome treatment (days 3, 8, and 18). A total of $250 \mu$ g each of $\alpha$-PD-1, RMP1-14 (BioXcell, West Lebanon, NH, USA) and $\alpha$-PD-L1, 10F.9G2 (BioXcell, West Lebanon, NH, USA) was given i.p. on days 9, 12, 15, and 18. Rationale for timing and injection site choice for checkpoint inhibitors: $\alpha$-CTLA-4 was given alongside the archaeosome vaccine s.c. so that it would drain to the same lymph nodes and act on the same CD8 ${ }^{+}$ $\mathrm{T}$ cells that were being activated by the vaccine. $\alpha$-PD-1 and $\alpha$-PD-L1 were given in parallel i.p. at the time when tumors were thought to be growing so they could systemically act on augmenting $\mathrm{CD} 8^{+} \mathrm{T}$ cells responses to the tumor.

\section{Results}

\subsection{MS-OVA Therapy Against B16-OVA Melanoma Induces OVA-CD8 $8^{+}$T Cells and Modest Tumor Protection}

The infiltration of a large number of tumor antigen-specific $\mathrm{CD} 8^{+} \mathrm{T}$ cells into tumor sites has been correlated with an improved outcome in colorectal, epithelial, ovarian, and metastatic tumors [26-28]. As archaeosomes have previously been shown to induce antigen-specific $\mathrm{CD} 8^{+} \mathrm{T}$ cell responses, we first evaluated the efficacy of MS-OVA in a therapeutic tumor model. C57BL/ 6 mice received $10^{6}$ B16-OVA s.c in the dorsal flank, followed by MS-OVA s.c. at the base of the tail on days 4,8 , and 18. Non-vaccinated control mice succumbed to tumor burden within 10-15 days, whereas therapeutic MS-OVA treatment extended the median survival to 31 days (Figure 1A). MS-OVA given in a tumor-bearing mouse was capable of activating and expanding OVA-CD8 ${ }^{+} \mathrm{T}$ cells from $0.1 \%$ (data not shown) up to $10 \%$ of all circulating $\mathrm{CD} 8^{+} \mathrm{T}$ cells in the blood sampled on days 15 and 30 after tumor challenge (Figure 1B). However, despite the presence of a large number of $\mathrm{OVA}_{257-264}$-specific $\mathrm{CD} 8^{+} \mathrm{T}$ cells, tumor growth continued. 
A

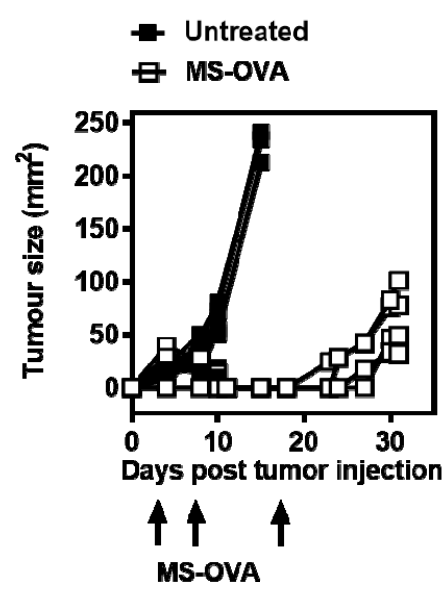

B

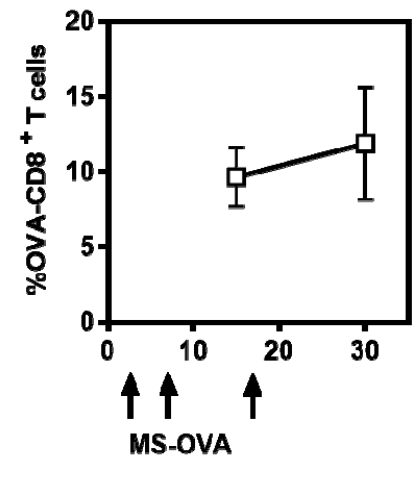

Figure 1. Therapeutic treatment of subcutaneous B16-ovalbumin (B-16-OVA) melanoma with Methanobrevibacter smithii-OVA (MS-OVA). C57BL/ 6 mice were given $10^{6}$ B16-OVA melanoma tumor cells subcutaneously (s.c.) in the dorsal flank. On days 4, 8, and 18 after tumor injection, $20 \mu \mathrm{g}$ MS-OVA was injected s.c. at the base of the tail away from the tumor site. (A): Tumor growth in individual mice is shown for vaccinated mice and non-vaccinated mice; $(\mathbf{B})$ : The mean frequency $\pm \mathrm{SD}$ of OVA-CD $8^{+} \mathrm{T}$ cells is shown at two time points for vaccinated mice ( $n=4$ /group). This was repeated twice.

In an attempt to improve responses, we evaluated different immunization schedules (Day 3 and 24; Day 3 and 8), however, while all vaccinated mice had smaller tumors than control mice, all but one succumbed to tumor burden and no discernible difference in protection was observed (Figure 2A,B). Since tumors grew so aggressively with $10^{6}$ B16-OVA tumor cells (median survival time of 10-15 days with a small therapeutic window) we also evaluated using lower tumor cell numbers. A starting dose of $10^{4}$ B16-OVA tumor cells resulted in slower tumor growth but not all animals developed tumors (data not shown). Likewise, with $10^{5}$ B16-OVA cells, the tumors also took longer to develop, however the variability between vaccinated mice also increased (Figure $2 \mathrm{C}$ ). We also compared mice vaccinated on a single (day 3 ) or triple occasion (day $3,10,29$ ) and while OVA-CD8 ${ }^{+} \mathrm{T}$ cell frequency increased with multiple vaccinations (Figure 2E) all mice had similar survival outcomes Figure 2D). Thus, while MS-OVA treatment increased time to tumor progression compared to control animals, there was no overall survival benefit with increased number of immunizations despite there being an increased frequency of $\mathrm{OVA}_{257-264}$-specific $\mathrm{CD}^{+} \mathrm{T}$ cells in the blood. This suggested that quality of $\mathrm{CD}^{+} \mathrm{T}$ cells (i.e., cytolytic capability) may have been impaired. 
A

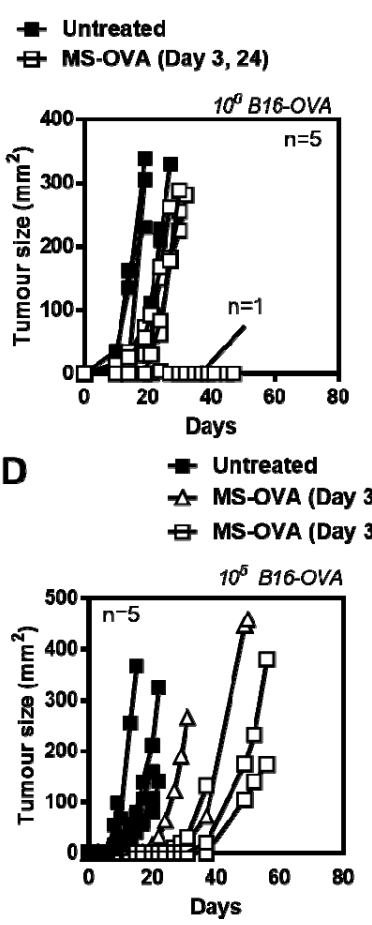

B
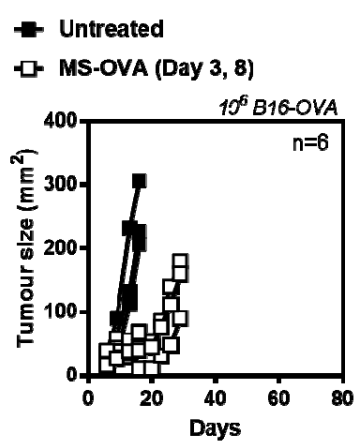

E
C

- Untreated

$\square$ MS-OVA (Day 3, 8)

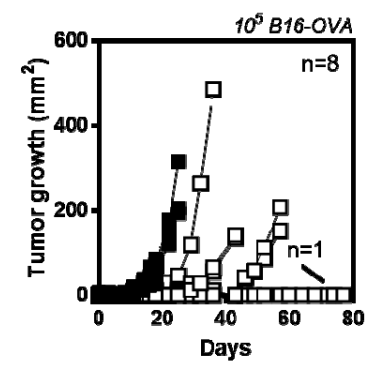

Figure 2. Optimizing MS-OVA treatment. C57BL/ 6 mice were given $10^{6}$ B16-OVA tumor cells s.c. in the dorsal flank, MS-OVA was given s.c. at the base of the tail on (A), day 3 and 24 or (B) day 3 and 8, and tumor growth was measured over time. Alternatively, a reduced number of tumor cells, $10^{5}$ of B16-OVA, were injected followed by MS-OVA treatment on (C) day 3 and 8, (D) day 3, or day 3, 10 and 29 , and tumor growth was measured. The mean frequency $\pm \mathrm{SD}$ of OVA-CD8 ${ }^{+} \mathrm{T}$ cells was compared in mice treated with MS-OVA on day 3 vs. days 3, 10, and 29 (E).

\subsection{OVA-CD8 ${ }^{+}$T Cell Cytotoxicity Is Impaired in Mice Bearing Solid B16-OVA Tumors}

To investigate whether functionality of OVA-CD8 ${ }^{+} \mathrm{T}$ cells induced by MS-OVA was impaired in B16-OVA tumor bearing mice, we used an in vivo cytotoxicity assay whereby vaccinated mice were injected with CFSE-stained target cells previously pulsed with OVA-peptide and non-pulsed cells as a control and the percentage of in vivo killing was calculated $24 \mathrm{~h}$ later based on the survival proportions of target cell populations.

Following administration of MS-OVA on an accelerated dosing schedule (day 3 and 8), at one week post the second dose, 94 to $98 \%$ of CFSE stained target cells were killed relative to non-target cells in both tumor and non-tumor-bearing mice (Figure 3A). As expected, tumor-bearing naïve non-immunized mice did not exhibit any killing of target cells (Figure $3 \mathrm{~A}$ ) indicating that the CD8 ${ }^{+} \mathrm{T}$ cell response to the endogenous tumor immunogen was negligible. From day 7 to 22, a loss of cytolytic ability was observed in both non-tumor bearing and tumor-bearing animals that were administered MS-OVA (Figure 3A). Since previous studies have shown that a high level (>80\%) of target-specific cytolytic ability can be maintained for extended periods of time ( 100 days post vaccination) with a more extended immunization schedule (day 3 and 24) [29], it is possible that the boosting schedule chosen (day 3 and 8 ) may not have been efficient to induce sustained cytolytic activity. Therefore, in a separate experiment, we also evaluated a more extended immunization schedule (day 3 and 24). Using this schedule, non-tumor bearing vaccinated mice maintained antigen-specific cytolytic ability by $\mathrm{CD}^{+} \mathrm{T}$ cells for the duration of the study as previously observed [29], however a decrease in cytolytic function was still observed in tumor-bearing mice over time (Figure 3B), suggesting impaired $\mathrm{CD}^{+} \mathrm{T}$ cell function by tumor suppressive mechanisms. It is also possible that the immunosuppression observed may not be antigen-dependent as we did not test this in a B16 model 
(without an OVA antigen). Since the modulation of timing of therapy on its own could not improve $\mathrm{CD}^{+} \mathrm{T}$ cell function, further investigation into the phenotype of responding OVA-CD8 ${ }^{+} \mathrm{T}$ cells was warranted.

A
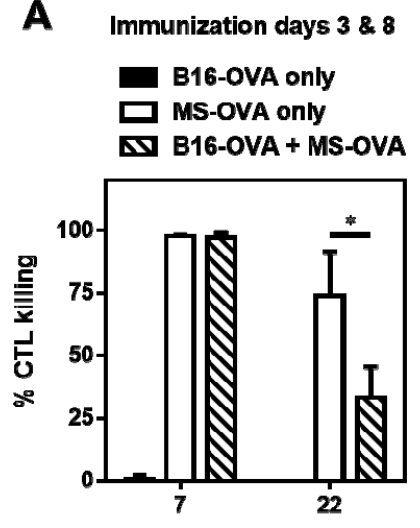

Days post last vaccination

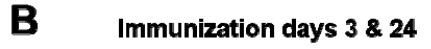

MS-OVA

D16-OVA + MS-OVA

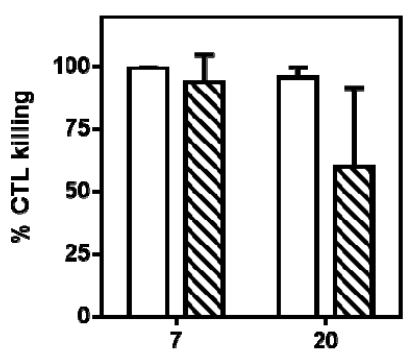

Days post last vaccination

Figure 3. In vivo cytotoxicity assay during immunotherapy with MS-OVA. Naïve C57BL/6 mice were given $10^{6}$ B16-OVA tumor cells s.c. on day 0 in the dorsal flank. A total of $20 \mu \mathrm{g}$ MS-OVA was administered s.c. at the base of the tail away from the tumor site. At 1 week or 3 weeks post boost, CFSE-stained target splenocytes were injected intravenously (i.v.); $24 \mathrm{~h}$ later recipient spleens were removed and processed to measure in vivo cytolytic killing. The different vaccination timings on day 3 and 8 (A), or 3 and 24 (B) were carried out in two separate experiments. The graphs show in vivo cytolytic killing for individual animals and the group mean $\pm \mathrm{SD}(n=3-5 /$ timepoint/group $)$ at 1 week and 3 weeks post boost. Mean $\pm \mathrm{SD}, n=3-5$ /timepoint/group. ${ }^{*} p=0.0308$ Unpaired two-tailed $t$ test was performed with GraphPad Prism software.

\subsection{Phenotype and Frequency of Responding OVA-CD $8^{+} T$ Cells}

We have previously demonstrated that the numbers of endogenous OVA-CD8 ${ }^{+} \mathrm{T}$ cells induced by MS-OVA can be low, making it difficult to track the phenotype of subpopulations over time. Therefore, the pool of available OVA-CD8 ${ }^{+} \mathrm{T}$ cells was increased by adoptively transferring splenocytes from an OT.1 mouse in which CD8 ${ }^{+} \mathrm{T}$ cells are specific for the OVA epitope SIINFEKL [30,31]. Since B16-OVA is considered an immunogenic tumor, we first investigated whether the tumor-derived OVA antigen could activate adoptively transferred OT.1 CD8 ${ }^{+} \mathrm{T}$ cells. Mice were injected with $10^{6}$ B16-OVA cells, and 3 days later $10^{4}, 10^{5}$, or $10^{6}$ OT.1 splenocytes were injected intravenously and the frequency of OVA-CD8 ${ }^{+} \mathrm{T}$ cells was monitored over time (Appendix A Figure A1A). The overall frequency of $\mathrm{OVA}_{257-264}$-specific $\mathrm{CD} 8^{+} \mathrm{T}$ cells was low (0.1-0.6\%) in all tested doses, and no statistically significant increase occurred over time. Importantly, there were no differences in B16-OVA tumor growth patterns in mice adoptively transferred with OT.1 cells (Appendix A Figure A1B).

To assess the phenotype of responding OVA-CD8 ${ }^{+} \mathrm{T}$ cells in this MS-OVA therapy model, C57BL/ 6 mice were first injected with $10^{6}$ B16-OVA cells, followed by the adoptive transfer of $10^{5}$ OT.1 splenocytes ( $\sim 10$ to $20 \%$ are OVA-CD8 ${ }^{+}$T cells, data not shown) 2 days later. Mice were then therapeutically treated with $20 \mu \mathrm{g}$ MS-OVA on day 3 and 8 and blood samples collected at various time-points (days 11, 18, and 30). As previously seen, immunization with MS-OVA decreased tumor growth and increased survival (median survival of 37 days) compared to non-vaccinated controls (median survival of 13 days) (Figure 4A). The presence of tumor did not appear to alter the frequency of responding $\mathrm{OVA}_{257-264}$-specific $\mathrm{CD} 8^{+} \mathrm{T}$ cells in the blood compared to a non-tumor-bearing vaccinated mouse (Figure 4B). CD62L and IL-7R $\alpha$ expression was also monitored with respect to responding OVA-CD8 ${ }^{+} \mathrm{T}$ cells to assess the quality of the response as both CD62L and IL-7R $\alpha$ are rapidly downregulated in effector $\mathrm{CD} 8^{+} \mathrm{T}$ cells and remain downregulated as long as cells are exposed to their cognate antigen. Re-upregulation of IL-7R $\alpha$ indicates a progression to memory phenotype. 
Expectedly, CD62L expression on CD8 ${ }^{+} \mathrm{T}$ cells in the blood of tumor-bearing mice was lower compared to non-tumor bearing mice; yet at later time-points, a similar level of expression of this marker was observed in both tumor and non-tumor bearing mice (Figure 4C). IL-7R $\alpha$ expression in OVA-CD8 ${ }^{+}$ $\mathrm{T}$ cells was statistically higher in tumor-bearing mice by day 30 (Figure 4D), but may be a result of IL-7R $\alpha^{\text {low }} \mathrm{CD}^{+} \mathrm{T}$ cells trafficking to the tumor site to exert effector functions.

A

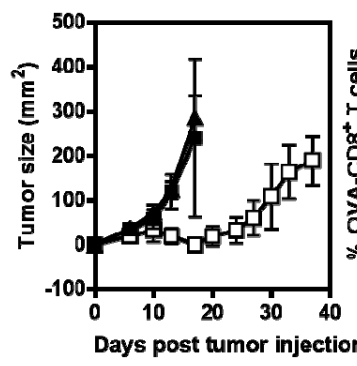

C

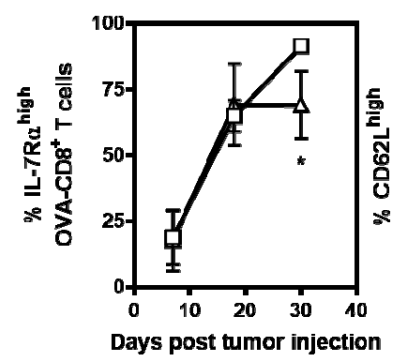

B

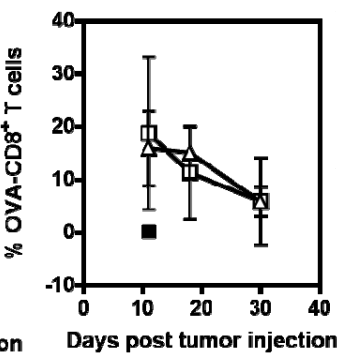

D

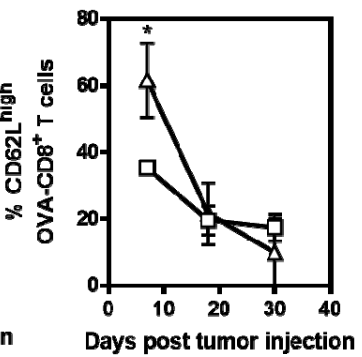

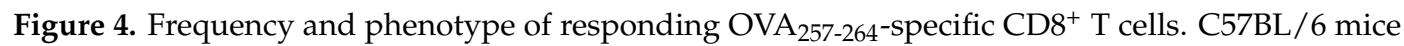
were given $10^{6}$ B16-OVA tumor cells s.c. in the dorsal flank. Two days later, $10^{5}$ OT.1 splenocytes were given intravenously. On days 3 and 8 after tumor injection, $20 \mu \mathrm{g}$ MS-OVA was injected s.c. at the base of the tail away from the tumor site. (A) Tumor growth was measured over time. At varying time points blood was collected for FACS analysis of (B) OVA-CD8 ${ }^{+} \mathrm{T}$ cells, and their expression of (C) CD62L and (D) IL-7R $\alpha$. Mean $\pm \mathrm{SD}, n=5$. Unpaired two-tailed $t$ test with Welch's correction for unequal variance $(\mathbf{C}) * p<0.05(\mathbf{D}) * p<0.05$.

\subsection{Tumor-Infiltrating CD8 $8^{+}$Cells Express PD-1 Following Therapeutic MS-OVA Treatment}

Programmed cell death protein-1 (PD-1) is upregulated on activated CD8 ${ }^{+} \mathrm{T}$ cells [32] and its maintained expression mediates the down-regulation of $\mathrm{CD} 8^{+} \mathrm{T}$ cell cytotoxicity and is thought to play a role in the immune evasion of tumors [33]. To characterize the phenotype of OVA-CD8 ${ }^{+} \mathrm{T}$ cells after MS-OVA therapy, mice were pre-dosed with OT.1 splenocytes to increase the basal frequency of OVA-specific $\mathrm{CD}^{+} \mathrm{T}$ cells, thereby increasing the frequency of responding OVA-specific $\mathrm{CD} 8^{+} \mathrm{T}$ cells. After tumor development, mice were sacrificed and blood, spleen, tumor and lymph nodes were taken to analyze tissue-resident OVA-specific CD8 ${ }^{+} \mathrm{T}$ cells and their phenotype. In MS-OVA treated mice, there was an increased frequency of OVA-specific $\mathrm{CD} 8^{+} \mathrm{T}$ cells in the tumor compared to the spleen, tumor-draining lymph nodes and the blood (Figure 5A). Surface expression of CD62L and IL-7R $\alpha$ was significantly higher in OVA-specific $\mathrm{CD} 8^{+} \mathrm{T}$ cells in the spleen and lymph nodes compared to the tumor (Figure 5B,C). Most, interestingly a significantly increased expression of PD-1 was observed in infiltrating OVA-specific $\mathrm{CD}^{+} \mathrm{T}$ cells compared to other sites (Figure 5D). Additionally, PD-1 expression was significantly lower on blood resident CD8 ${ }^{+} \mathrm{T}$ cells. Since PD-1 upregulation has been correlated with diminished T cell function [34], this could represent a loss of tumor control and may account for loss of CTL function and resurgence of tumor after MS-OVA therapy. 
A
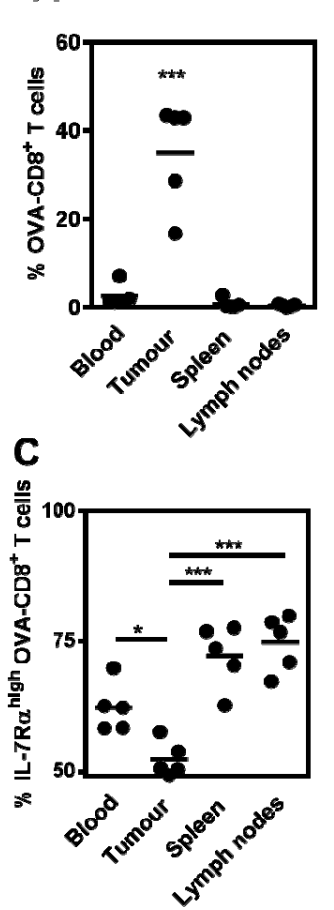

B

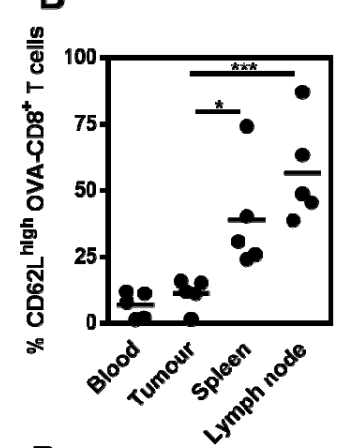

D

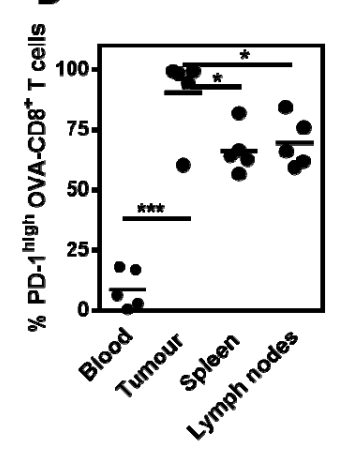

Figure 5. Phenotype and location of responding $\mathrm{OVA}_{257-264}$-specific $\mathrm{CD} 8^{+} \mathrm{T}$ cells in MS-OVA-vaccinated tumor bearing mice. C57BL/ 6 mice were given $10^{6}$ B16-OVA tumor cells s.c. in the dorsal flank. Two days later, $10^{5}$ OT.1 splenocytes were given intravenously. On days 3 and 8 after tumor injection, $20 \mu \mathrm{g}$ MS-OVA was injected s.c. at the base of the tail away from the tumor site. At days 33 and 37 post tumor injection, blood was collected and organs excised and processed to single cell suspensions for FACS analysis. The $\%$ of OVA-CD8 ${ }^{+} \mathrm{T}$ cells $(\mathrm{A})$ and the frequency of CD62L high $(\mathbf{B})$, IL-7R $\alpha^{\text {high }}(\mathbf{C})$ or PD-1 $1^{\text {high }}(\mathrm{D})$ was measured (mean $\pm \mathrm{SD}, n=5$ ). One-way ANOVA and Dunnet's post tests are as follows: ${ }^{* * *}(F(3,16)=37.69, p<0.0001)$, tumor vs. all $\left.{ }^{* * *} p<0.0001\right),{ }^{* * *}(F(3,16)=13.05, p<0.0001)$, tumor vs. spleen ${ }^{*} p<0.05$, tumor vs. lymph nodes ${ }^{* * *} p<0.0001$. ${ }^{* * *}(F(3,16)=21.08, p<0.0001)$, tumor vs. blood ${ }^{*} p<0.05$, tumor vs. spleen ${ }^{* * *} p<0.0001$, tumor vs. lymph nodes ${ }^{* * *} p<0.0001$. $* * *(F(3,16)=44.43, p<0.0001)$, tumor vs. blood ${ }^{* * *} p<0.0001$, tumor vs. spleen ${ }^{*} p<0.05$, tumor vs. lymph nodes ${ }^{*} p<0.05$.

\subsection{Combination Checkpoint Inhibitor Therapy with MS-OVA}

To address the question of whether T cell inhibitory receptors or ligands, such as PD-1, CTLA-4 and PD-L1, were responsible for the impaired OVA-CD8 ${ }^{+} \mathrm{T}$ cell function and resumed tumor growth, we next evaluated whether antibody therapy targeting these molecules would enhance the efficacy of MS-OVA therapy in B16-OVA tumor-bearing mice. B16-OVA bearing C57BL/ 6 mice were treated on day 3, 8, and 18 after tumor injection with both MS-OVA (day 3, 8 and 18) and/or $\alpha$ CTLA-4 (day 3, 8, and 18) and/or $\alpha$ PD-1/ $\alpha$ PD-L1 (day 9, 12, 15, and 18). We chose to use both $\alpha$ PD-1 and $\alpha$ PD-L1 to block the entire PD-1/PD-L1 pathway as each molecule is known to bind to other ligands mediating immunosuppression $[35,36]$. Survival was significantly improved when MS-OVA archaeosomes were used in combination with checkpoint inhibitors with best responses obtained with a combination of MS-OVA archaeosomes $+\alpha$ CTLA- $4 / \alpha$ PD-1 $/ \alpha$ PD-L1 (Figure 6 ). Indeed, using this combination, $70 \%$ of animals survived beyond 80 days compared to a median survival of 21 and 22 days for MS-OVA or $\alpha$ CTLA-4/ $\alpha$ PD-1/ $\alpha$ PD-L1 checkpoint inhibitor therapy alone, respectively. Weaker responses were obtained with MS-OVA $+\alpha$ CTLA- 4 (median survival $=32$ days), MS-OVA $+\alpha$ PD-1/ $\alpha$ PD-L1 $($ median survival $=34$ days $), \alpha$ CTLA-4 alone (median survival $=23$ days), or $\alpha$ PD- $1 / \alpha$ PD-L1 (median survival $=18.5$ days) (data not shown). 
A
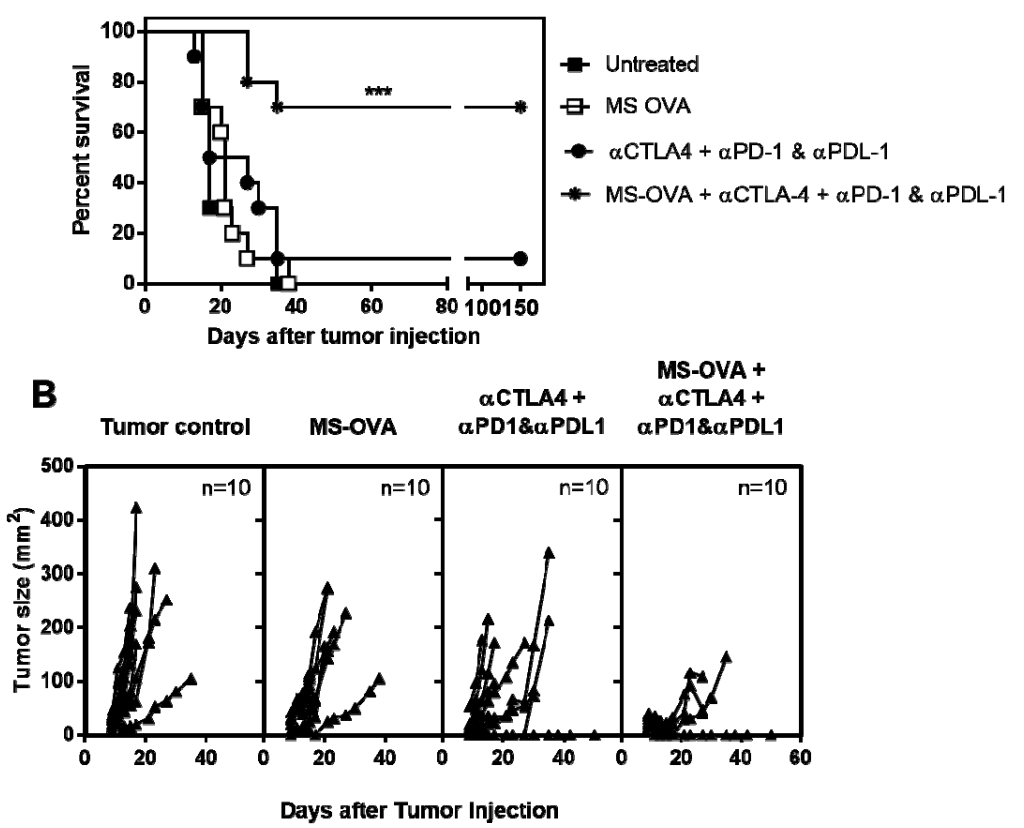

Figure 6. MS-OVA therapy in combination with checkpoint inhibitor therapy significantly improves survival outcome. C57BL/ 6 mice were given $5 \times 10^{5}$ B16-OVA tumor cells s.c. in the dorsal flank; 3, 8 , and 18 days later $20 \mu \mathrm{g}$ MS-OVA was injected s.c. at the base of the tail away from the tumor site. In total $100 \mu \mathrm{g} \alpha \mathrm{CTLA}-4$ (Clone 9D9) was given s.c. alongside the archaeosome vaccination. Then, $250 \mu$ g each of $\alpha$ PD-1 (clone: RMP1-14) and $\alpha$ PD-L1 (clone: 10F.9G2) was given i.p on days 9, 12, 15, and 18. Log-rank Mantel Cox test, ${ }^{* * *} p<0.001$. This study was repeated to confirm results.

\section{Discussion}

The presence of anti-tumor $\mathrm{CD}^{+} \mathrm{T}$ cells within a tumor can be a positive prognostic factor which correlates with the presence of intratumoral granzyme B, IFN- $\gamma$ and IL-2, hallmarks of cytolytic CD8 ${ }^{+}$ $\mathrm{T}$ cell responses $[28,37,38]$. However, while large numbers of $\mathrm{CD}^{+} \mathrm{T}$ cells can be found in some types of tumors, tumor progression often still persists; in these cases inhibitory mechanisms such as the immunosuppressive CD8 ${ }^{+} \mathrm{T}$ cell receptors, PD-1, and CTLA-4 as well as tumor-expressed PD-L1 are often involved. In investigating the usefulness of MS-OVA to induce potent $\mathrm{CD}^{+} \mathrm{T}$ cell responses in a therapeutic tumor model, we observed that while MS-OVA could induce antigen-specific CD8 ${ }^{+} \mathrm{T}_{\text {cells }}$ in tumor-bearing mice which resulted in a decrease in tumor burden and even a short tumor-free period, tumor recurrence occurred and mice eventually succumbed to tumor burden. To determine whether responses could be improved by increasing the frequency of anti-tumor $\mathrm{CD}^{+} \mathrm{T}$ cells, we evaluated different immunization schedules and showed that while boosting with MS-OVA could increase the frequency of $\mathrm{CD}^{+} \mathrm{T}$ cells, overall tumor protection in the therapeutic setting did not significantly improve compared to a single dose vaccine. For example, a similar rate of tumor occurrence, was obtained with 1, 2, or 3 immunizations regardless of boosting interval or level of OVA $257-264$ specific $\mathrm{CD}^{+} \mathrm{T}$ cell frequency. Since it was possible that tumor challenge dose was simply too high for any anti-tumor immune responses to be effective, we reduced the tumor challenge dose from $10^{6}$ to $10^{5}$ B16-OVA cells. However, while the onset of tumor was expectedly delayed, no difference in vaccine efficacy could be achieved. Likewise, it was possible that the time interval between priming and boosting with MS-OVA was too short to propagate large numbers of OVA $257-264$-specific $\mathrm{CD}^{+} \mathrm{T}$ cells and so we increased this in an attempt to generate higher frequencies of CD8 ${ }^{+} \mathrm{T}$ cells. Indeed, an in vivo cytotolytic assay confirmed that in the absence of tumor, a second dose of MS-OVA at an early time-point (5 days after priming) reduced the maintenance of $\mathrm{CD} 8^{+} \mathrm{T}$ cell cytotoxicity, whereas delaying the second dose to a later time-point (21 days later) maintained cytotoxicity at $\sim 100 \%$ 
even up to 3 weeks after the booster dose. However, when this was evaluated in tumor-bearing mice, there was a decrease in in vivo cytolytic activity regardless of time interval prior to boosting and no enhancement of tumor protection. It is possible that delaying a booster vaccination in a tumor-bearing mouse by 2 weeks failed because tumor burden was much too large by this time-point and that CD $8^{+}$ $\mathrm{T}$ cell cytotoxicity was impaired by tumor-suppressive mechanisms, highlighting the requirement not only for robust anti-tumor immune responses but also combinatorial approaches to mitigate tumor-mediated immunosuppression. It is possible that responses may have been improved by using a heterologous prime-boost regime as has been reported by other groups $[39,40]$ however, we did not evaluate this as we have previously shown that archaeosomes work effectively for both priming and boosting and are capable of inducing high levels of antigen-specific CD8 ${ }^{+} \mathrm{T}$ cells $\left.[15,16,29]\right]$. Moreover this approach is not likely to overcome immunosuppression in the tumor. Immune suppressive mechanisms can be evoked by tumors that can reduce the effectiveness of anti-tumor $\mathrm{CD}^{+} \mathrm{T}$ cells. These mechanisms include the up-regulation of inhibitory receptors such as PD-1 on $\mathrm{CD}^{+} \mathrm{T}$ cells $[41,42]$. In our study, tumor-bearing mice treated therapeutically with MS-OVA generated OVA-specific $\mathrm{CD}^{+} \mathrm{T}$ cell responses in the blood that when compared to non-tumor bearing mice had a slightly lower number of IL-7R $\alpha$ high cells and the same low number of CD62L high cells at a time-point when the tumors were measured to be growing. This phenotype indicates a mixed population of effector $\mathrm{CD}^{+} \mathrm{T}$ cells $\left(\mathrm{T}_{\mathrm{E}}\right)$ and effector memory $\mathrm{CD}^{+} \mathrm{T}$ cells $\left(\mathrm{T}_{\mathrm{EM}}\right)$. In a prophylactic vaccination setting a $\mathrm{T}_{\mathrm{E}} / \mathrm{T}_{\mathrm{EM}}$ phenotype is thought to be less effective compared to a predominant central memory $\mathrm{CD}^{+} \mathrm{T}$ cell $\left(\mathrm{T}_{\mathrm{CM}}\right)$ phenotype due to their limited proliferation potential [43], however in a therapeutic setting with the continued persistence of OVA antigen in the tumor it is not unexpected that they express an activated effector phenotype and others have shown this to correlate with a higher level of PD-1 expression [44].

In MS-OVA treated tumor bearing mice, tumor growth was suppressed for a short period of time, however when tumor returned, $\mathrm{CD}^{+} \mathrm{T}$ cells located within the tumor tissue, spleen, and lymph nodes notably exhibited high levels of PD-1 expression $(90 \%, 66 \%$, and $70 \%$, respectively). The induction of inhibitory receptors after vaccination has previously been shown in both preclinical models and in humans and so was not entirely unexpected $[45,46]$. These increases of PD- 1 expression in $\mathrm{CD}^{+} \mathrm{T}$ cells highlight a possible cause for the relapse of tumor growth in this vaccination scenario, suggesting the use of a combination therapy that includes targeting PD-1 with antibody therapy. The use of a blocking antibodies against PD-1 can rescue CD8 ${ }^{+} \mathrm{T}$ cell lytic abilities [47]. Similarly, targeting PD-1, PD-L1, and CTLA-4 with monoclonal antibodies has been shown to reverse CD8 ${ }^{+} \mathrm{T}$ cell exhaustion and enhance lytic capabilities [48-50] as well as promote tumor shrinkage and survival for many cancer patients [51-53]. Successes in clinical trials have led to the approval of a number of checkpoint inhibitor therapies by national health authorities (US Food and Drug Administration, Health Canada etc.) for use against multiple tumor indications $[7,53]$. Checkpoint inhibitor therapy has even been approved for use as a monotherapy, its mode of action being to 'remove the brakes' on a patient's existing tumor-specific $\mathrm{CD}^{+} \mathrm{T}$ cells. However, these therapies, which include $\alpha$ PD-1, $\alpha$ PD-L1, and $\alpha$ CTLA-4, have been observed to be ineffective in certain circumstances that include immunologically cold tumors where physical barriers impede immune cell invasion, or when tumor-specific $\mathrm{T}$ cells are not present at all. In the latter situation, a good approach would be to combine checkpoint inhibitor therapy with a vaccine that can boost the level of circulating tumor-specific T cells. Indeed, a synergy between antibodies blocking inhibitory pathways and various types of cancer vaccines including peptide vaccines, live vectors, dendritic cell targeting inert vectors, cellular vaccines, and DNA vaccines has previously been reported [54]. Since we observed that following vaccination there was an increased expression of PD-1 in tumor infiltrating CD8 ${ }^{+} \mathrm{T}$ cells, we sought to evaluate whether the efficacy of MS-OVA could be improved by combining with commercially available antibodies against PD-1 and other inhibitory receptors. Treatment of B16-OVA with all three checkpoint inhibitors alone (i.e., without vaccines) did not enhance survival greater than for the control. This was not unexpected since B16-OVA does not induce tumor-specific T cells, and for antibodies which block 
inhibitory pathways to be effective, there is a requirement for pre-existing anti-tumor $\mathrm{CD}^{+} \mathrm{T}$ cells at the tumor site [55]. When MS-OVA was combined with $\alpha$ CTLA- 4 or with a combination of both $\alpha$ PD- 1 and $\alpha$ PD-L1, there was a slight improvement in survival although over $90 \%$ of animals did eventually succumb to tumor (data not shown). However, when a combination of MS-OVA with $\alpha$ CTLA-4, $\alpha$ PD- 1 , and $\alpha$ PD-L2 was used, $70 \%$ of animals survived beyond 100 days compared to a median survival of 21 and 22 days for MS-OVA or $\alpha$ CTLA-4/ $\alpha$ PD-1/ $\alpha$ PD-L1 checkpoint inhibitor therapy alone, respectively. While this is the first report of checkpoint inhibitors in combination with an archaeosome-based vaccine, our findings also support previous studies using the B16-OVA model in mice whereby a Salmonella typhimurium-based vaccine was used to deliver the OVA SIINFEKL epitope and resulted in 32\% rejection of long-established tumors which could be increased to $80 \%$ when the vaccine was combined with $\alpha$ PD-L1 or $\alpha$ PD-L1 plus $\alpha$ CTLA-4 [56]. Likewise, an Fms-like tyrosine kinase 3 (Flt3)-based tumor cell vaccine combined with blocking antibodies directed against CTLA-4, PD-1, and PD-L1 resulted in rejection of B16 melanoma tumors in 65\% of mice, compared to $10 \%$ with vaccine plus $\alpha$ CTLA- 4 alone, $25 \%$ with vaccine plus $\alpha \mathrm{PD}-1$ alone and $50 \%$ with vaccine plus $\alpha$ CTLA- 4 combined with $\alpha$ PD-1 [57]. Dual blockade of both PD- 1 and CTLA- 4 in combination with tumor vaccine has also been shown to enhance tumor rejection in other mouse tumor models such as CT26 colon carcinoma and ID8-VEGF ovarian carcinoma [58]. A number of other checkpoint inhibitor-targeting antibodies have also been previously used with cancer vaccines, including $\alpha$-Tim-3, $\alpha$-Tim-4, $\alpha$-OX40 [54] and it is likely that these would also be beneficial if used in combination with our archaeosome-based vaccine. Indeed future studies with archaeosomes in tumor therapy will involve testing of novel checkpoint inhibitors as well as testing of these combinations with more clinically relevant tumor associated antigens such as Trp2, for which archaeosomes have previously been shown to break tolerance to [15]. Archaeosomes possess extremely high stability due to their unique chemical constitutions and have been shown to have a high safety profile and to activate antigen-specific CD8 ${ }^{+}$ $\mathrm{T}$ cell responses in multiple studies to date, making them an appropriate choice for adjuvanting an anti-tumor vaccine [12]. Herein, the combination of an archaeosome-based vaccine and checkpoint inhibitors directed against PD-1, PD-L1, and CTLA-4 had a clear synergistic effect, improving overall survival of B16-OVA-bearing mice being treated therapeutically, and shows a clear benefit for the use of therapeutic vaccines such as archaeosomes in modern cancer therapy regimes.

\section{Conclusions}

Herein, we have shown that an archaeosome-based vaccine alone will induce OVA-CD8 ${ }^{+} \mathrm{T}$ cells capable of providing short-term protection in therapy against solid subcutaneous B16-OVA in mice and that this correlated with a high level of PD- 1 expression on tumor-infiltrating OVA-CD8 ${ }^{+}$ $\mathrm{T}$ cells. However, when this was combined with antibodies directed against the $\mathrm{CD} 8^{+} \mathrm{T}$ cell inhibitory receptors PD-1 and CTLA-4 as well as the inhibitory ligand PD-L1 we were able to obtain long-lasting protection from the B16-OVA tumor in $70 \%$ of C57BL/ 6 mice. Thus, an archaeosome-based vaccine in combination with checkpoint inhibitor therapy offers an attractive approach to promote long-term tumor protection.

Acknowledgments: The authors would like to acknowledge Edith Lord for gifting B16-OVA. This study was conducted in part with the support of the Ontario Institute for Cancer Research through funding provided by the Government of Ontario, Canada.

Author Contributions: F.C.S., M.J.M., R.D.W. and L.K. conceived and designed the experiments; F.C.S., L.D., K.G. and R.D. performed the experiments; F.C.S., M.J.M. and L.K. analyzed and interpreted the data; M.M., R.W. and L.K. contributed reagents/materials/analysis tools; F.C.S., M.J.M., R.D.W. and L.K. contributed to writing the paper.

Conflicts of Interest: The authors declare no conflict of interest. 


\section{Appendix A}

A

B
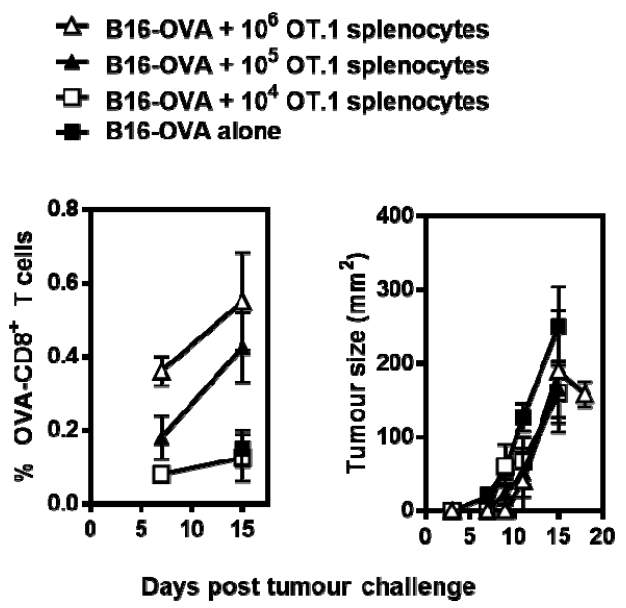

Figure A1. Basal level of circulating OVA-CD8 ${ }^{+} \mathrm{T}$ cells and the optimization of adoptively transferred OT.1 splenocytes for tracking OVA-CD8 ${ }^{+} \mathrm{T}$ cell responses. C57BL/ 6 mice were challenged s.c. with $10^{6}$ B16-OVA. 3 days later PBS control, $10^{4}, 10^{5}$ or $10^{6}$ OT.1 splenocytes are injected i.v. (A) Blood samples are taken to monitor $\mathrm{OVA}_{257-264}$ specific $\mathrm{CD}^{+} \mathrm{T}$ cells; (B) Tumor size was monitored over time. (Mean \pm SE, $n=5$ /group).

\section{References}

1. Hamm, C.; Petrella, T.; Verma, S. Biochemotherapy for the treatment of metastatic malignant melanoma: A systematic review. Cancer Treat. Rev. 2008, 34, 145-156. [CrossRef] [PubMed]

2. Larkin, J.; Chiarion-Sileni, V.; Gonzalez, R.; Grob, J.J.; Cowey, C.L.; Lao, C.D.; Schadendorf, D.; Dummer, R.; Smylie, M.; Rutkowski, P.; et al. Combined Nivolumab and Ipilimumab or Monotherapy in Untreated Melanoma. N. Engl. J. Med. 2015, 373, 23-34. [CrossRef] [PubMed]

3. Postow, M.A.; Chesney, J.; Pavlick, A.C.; Robert, C.; Grossmann, K.; McDermott, D.; Linette, G.P.; Meyer, N.; Giguere, J.K.; Agarwala, S.S.; et al. Nivolumab and Ipilimumab versus Ipilimumab in Untreated Melanoma. N. Engl. J. Med. 2015, 372, 2006-2017. [CrossRef] [PubMed]

4. Balch, C.M.; Gershenwald, J.E.; Soong, S.; Thompson, J.F.; Atkins, M.B.; Byrd, D.R.; Buzaid, A.C.; Cochran, A.J.; Coit, D.G.; Ding, S.; et al. Final Version of 2009 AJCC Melanoma Staging and Classification. J. Clin. Oncol. 2009, 27, 6199-6206. [CrossRef] [PubMed]

5. Sznol, M.; Kluger, H.M.; Callahan, M.K.; Postow, M.A.; Gordon, R.A.; Segal, N.H.; Rizvi, N.; Lesokhin, A.; Atkins, M.B.; Kirkwood, J.; et al. Survival, response duration, and activity by BRAF mutation (MT) status of nivolumab (NIVO, anti-PD-1, BMS-936558, ONO-4538) and ipilimumab (IPI) concurrent therapy in advanced melanoma (MEL). J. Clin. Oncol. 2014, 32, LBA9003. [CrossRef]

6. Wolchok, J.D.; Kluger, H.; Callahan, M.K.; Postow, M.A.; Rizvi, N.A.; Lesokhin, A.M.; Segal, N.H.; Ariyan, C.E.; Gordon, R.-A.; Reed, K.; et al. Nivolumab plus Ipilimumab in Advanced Melanoma. N. Engl. J. Med. 2013, 369, 122-133. [CrossRef] [PubMed]

7. Redman, J.M.; Gibney, G.T.; Atkins, M.B. Advances in immunotherapy for melanoma. BMC Med. 2016, 14, 20. [CrossRef] [PubMed]

8. Maia, M.C.; Hansen, A.R. A comprehensive review of immunotherapies in prostate cancer. Crit. Rev. Oncol. Hematol. 2017, 113, 292-303. [CrossRef] [PubMed]

9. Brustugun, O.T.; Sprauten, M.; Helland, Å. Real-world data on nivolumab treatment of non-small cell lung cancer. Acta Oncol. Stockh. Swed. 2017, 56, 438-440. [CrossRef] [PubMed]

10. Zibelman, M.; Ramamurthy, C.; Plimack, E.R. Emerging role of immunotherapy in urothelial carcinoma-Advanced disease. Urol. Oncol. 2016, 34, 538-547. [CrossRef] [PubMed] 
11. Hude, I.; Sasse, S.; Engert, A.; Bröckelmann, P.J. The emerging role of immune checkpoint inhibition in malignant lymphoma. Haematologica 2017, 102, 30-42. [CrossRef] [PubMed]

12. Haq, K.; Jia, Y.; Krishnan, L. Archaeal lipid vaccine adjuvants for induction of cell-mediated immunity. Expert Rev. Vaccines 2016, 15, 1-10. [CrossRef] [PubMed]

13. Krishnan, L.; Dicaire, C.J.; Patel, G.B.; Sprott, G.D. Archaeosome vaccine adjuvants induce strong humoral, cell-mediated, and memory responses: Comparison to conventional liposomes and alum. Infect. Immun. 2000, 68, 54-63. [CrossRef] [PubMed]

14. Krishnan, L.; Sad, S.; Patel, G.B.; Sprott, G.D. Archaeosomes induce long-term CD8+ cytotoxic T cell response to entrapped soluble protein by the exogenous cytosolic pathway, in the absence of CD4+ T cell help. J. Immunol. 2000, 165, 5177-5185. [CrossRef] [PubMed]

15. Krishnan, L.; Deschatelets, L.; Stark, F.C.; Gurnani, K.; Sprott, G.D. Archaeosome adjuvant overcomes tolerance to tumor-associated melanoma antigens inducing protective CD8 T cell responses. Clin. Dev. Immunol. 2010, 2010, 578432. [CrossRef] [PubMed]

16. Stark, F.C.; McCluskie, M.J.; Krishnan, L. Homologous Prime-Boost Vaccination with OVA Entrapped in Self-Adjuvanting Archaeosomes Induces High Numbers of OVA-Specific CD8 ${ }^{+}$T Cells that Protect Against Subcutaneous B16-OVA Melanoma. Vaccines 2016, 4, 44. [CrossRef] [PubMed]

17. Gattinoni, L.; Klebanoff, C.A.; Palmer, D.C.; Wrzesinski, C.; Kerstann, K.; Yu, Z.; Finkelstein, S.E.; Theoret, M.R.; Rosenberg, S.A.; Restifo, N.P.; et al. Acquisition of full effector function in vitro paradoxically impairs the in vivo antitumor efficacy of adoptively transferred CD8+ T cells. J. Clin. Investig. 2005, 15, 1616-1626. [CrossRef] [PubMed]

18. Klebanoff, C.A.; Gattinoni, L.; Restifo, N.P. CD8+ T-cell memory in tumor immunology and immunotherapy. Immunol. Rev. 2006, 211, 214-224. [CrossRef] [PubMed]

19. Klebanoff, C.A.; Gattinoni, L.; Palmer, D.C.; Muranski, P.; Ji, Y.; Hinrichs, C.S.; Borman, Z.A.; Kerkar, S.P.; Scott, C.D.; Finkelstein, S.E.; et al. Determinants of Successful CD8+ T-Cell Adoptive Immunotherapy for Large Established Tumors in Mice. Clin. Cancer Res. 2011, 17, 5343-5352. [CrossRef] [PubMed]

20. Pardoll, D.M. The blockade of immune checkpoints in cancer immunotherapy. Nat. Rev. Cancer 2012, 12, 252-264. [CrossRef] [PubMed]

21. Krishnan, L.; Gurnani, K.; Dicaire, C.J.; van Faassen, H.; Zafer, A.; Kirschning, C.J.; Sad, S.; Sprott, G.D. Rapid clonal expansion and prolonged maintenance of memory CD8+ T cells of the effector (CD44highCD62Llow) and central (CD44highCD62Lhigh) phenotype by an archaeosome adjuvant independent of TLR2. J. Immunol. 2007, 178, 2396-2406. [CrossRef] [PubMed]

22. Russell, M.S.; Iskandar, M.; Mykytczuk, O.L.; Nash, J.H.E.; Krishnan, L.; Sad, S. A reduced antigen load in vivo, rather than weak inflammation, causes a substantial delay in CD8+ T cell priming against Mycobacterium bovis (bacillus Calmette-Guérin). J. Immunol. 2007, 179, 211-220. [CrossRef] [PubMed]

23. Brown, D.M.; Fisher, T.L.; Wei, C.; Frelinger, J.G.; Lord, E.M. Tumours can act as adjuvants for humoral immunity. Immunology 2001, 102, 486-497. [CrossRef] [PubMed]

24. Dudani, R.; Chapdelaine, Y.; Faassen, H.V.; Smith, D.K.; Shen, H.; Krishnan, L.; Sad, S. Multiple mechanisms compensate to enhance tumor-protective CD8(+) T cell response in the long-term despite poor CD8(+) T cell priming initially: Comparison between an acute versus a chronic intracellular bacterium expressing a model antigen. J. Immunol. 2002, 168, 5737-5745. [CrossRef] [PubMed]

25. Barber, D.L.; Wherry, E.J.; Ahmed, R. Cutting edge: Rapid in vivo killing by memory CD8 T cells. J. Immunol. 2003, 171, 27-31. [CrossRef] [PubMed]

26. Cheever, M.A.; Higano, C. PROVENGE (Sipuleucel-T) in Prostate Cancer: The First FDA Approved Therapeutic Cancer Vaccine. Clin. Cancer Res. 2011, 17, 3520-3526. [CrossRef] [PubMed]

27. Dudley, M.E.; Rosenberg, S.A. Adoptive-cell-transfer therapy for the treatment of patients with cancer. Nat. Rev. Cancer 2003, 3, 666-675. [CrossRef] [PubMed]

28. Naito, Y.; Saito, K.; Shiiba, K.; Ohuchi, A.; Saigenji, K.; Nagura, H.; Ohtani, H. CD8+ T cells infiltrated within cancer cell nests as a prognostic factor in human colorectal cancer. Cancer Res. 1998, 58, 3491-3494. [PubMed]

29. Krishnan, L.; Sprott, G.D. Archaeosome adjuvants: Immunological capabilities and mechanism(s) of action. Vaccine 2008, 26, 2043-2055. [CrossRef] [PubMed]

30. Hogquist, K.A.; Jameson, S.C.; Heath, W.R.; Howard, J.L.; Bevan, M.J.; Carbone, F.R. Pillars article: T cell receptor antagonist peptides induce positive selection. Cell. 1994. 76: 17-27. J. Immunol. Baltim. Md 1950 2012, 188, 2046-2056. 
31. Hogquist, K.A.; Jameson, S.C.; Heath, W.R.; Howard, J.L.; Bevan, M.J.; Carbone, F.R. T cell receptor antagonist peptides induce positive selection. Cell 1994, 76, 17-27. [CrossRef]

32. Agata, Y.; Kawasaki, A.; Nishimura, H.; Ishida, Y.; Tsubata, T.; Yagita, H.; Honjo, T. Expression of the PD-1 antigen on the surface of stimulated mouse T and B lymphocytes. Int. Immunol. 1996, 8, 765-772. [CrossRef] [PubMed]

33. Blank, C.; Gajewski, T.F.; Mackensen, A. Interaction of PD-L1 on tumor cells with PD-1 on tumor-specific T cells as a mechanism of immune evasion: Implications for tumor immunotherapy. Cancer Immunol. Immunother. 2005, 54, 307-314. [CrossRef] [PubMed]

34. Hodi, F.S.; Dranoff, G. The biologic importance of tumor-infiltrating lymphocytes. J. Cutan. Pathol. 2010, 37 (Suppl. 1), 48-53. [CrossRef] [PubMed]

35. Osada, T.; Patel, S.P.; Hammond, S.A.; Osada, K.; Morse, M.A.; Lyerly, H.K. CEA/CD3-bispecific T cell-engaging (BiTE) antibody-mediated T lymphocyte cytotoxicity maximized by inhibition of both PD1 and PD-L1. Cancer Immunol. Immunother. 2015, 64, 677-688. [CrossRef] [PubMed]

36. Peggs, K.S. Recent advances in antibody-based therapies for Hodgkin Lymphoma. Br. J. Haematol. 2015, 171, 171-178. [CrossRef] [PubMed]

37. Zhang, L.; Conejo-Garcia, J.R.; Katsaros, D.; Gimotty, P.A.; Massobrio, M.; Regnani, G.; Makrigiannakis, A.; Gray, H.; Schlienger, K.; Liebman, M.N.; et al. Intratumoral T cells, recurrence, and survival in epithelial ovarian cancer. N. Engl. J. Med. 2003, 348, 203-213. [CrossRef] [PubMed]

38. Rosenberg, S.A.; Dudley, M.E. Adoptive cell therapy for the treatment of patients with metastatic melanoma. Curr. Opin. Immunol. 2009, 21, 233-240. [CrossRef] [PubMed]

39. Lu, S. Heterologous prime-boost vaccination. Curr. Opin. Immunol. 2009, 21, 346-351. [CrossRef] [PubMed]

40. Ishizaki, H.; Song, G.-Y.; Srivastava, T.; Carroll, K.D.; Shahabi, V.; Manuel, E.R.; Diamond, D.J.; Ellenhorn, J.D.I. Heterologous prime/boost immunization with p53-based vaccines combined with Toll-like receptor stimulation enhances tumor regression. J. Immunother. 2010, 33, 609-617. [CrossRef] [PubMed]

41. Chapon, M.; Randriamampita, C.; Maubec, E.; Badoual, C.; Fouquet, S.; Wang, S.-F.; Marinho, E.; Farhi, D.; Garcette, M.; Jacobelli, S.; et al. Progressive Upregulation of PD-1 in Primary and Metastatic Melanomas Associated with Blunted TCR Signaling in Infiltrating T Lymphocytes. J. Investig. Dermatol. 2011, 131, 1300-1307. [CrossRef] [PubMed]

42. Inozume, T.; Hanada, K.-I.; Wang, Q.J.; Ahmadzadeh, M.; Wunderlich, J.R.; Rosenberg, S.A.; Yang, J.C. Selection of CD8+PD-1+ lymphocytes in fresh human melanomas enriches for tumor-reactive $\mathrm{T}$ cells. J. Immunother. 2010, 33, 956-964. [CrossRef] [PubMed]

43. Stark, F.C.; Sad, S.; Krishnan, L. Intracellular bacterial vectors that induce CD8(+) T cells with similar cytolytic abilities but disparate memory phenotypes provide contrasting tumor protection. Cancer Res. 2009, 69, 4327-4334. [CrossRef] [PubMed]

44. Sckisel, G.D.; Mirsoian, A.; Minnar, C.M.; Crittenden, M.; Curti, B.; Chen, J.Q.; Blazar, B.R.; Borowsky, A.D.; Monjazeb, A.M.; Murphy, W.J. Differential phenotypes of memory CD4 and CD8 T cells in the spleen and peripheral tissues following immunostimulatory therapy. J. Immunother. Cancer 2017, 5, 33. [CrossRef] [PubMed]

45. Fourcade, J.; Sun, Z.; Pagliano, O.; Chauvin, J.-M.; Sander, C.; Janjic, B.; Tarhini, A.A.; Tawbi, H.A.; Kirkwood, J.M.; Moschos, S.; et al. PD-1 and Tim-3 regulate the expansion of tumor antigen-specific $\mathrm{CD}^{+} \mathrm{T}$ cells induced by melanoma vaccines. Cancer Res. 2014, 74, 1045-1055. [CrossRef] [PubMed]

46. Badoual, C.; Hans, S.; Merillon, N.; Van Ryswick, C.; Ravel, P.; Benhamouda, N.; Levionnois, E.; Nizard, M.; Si-Mohamed, A.; Besnier, N.; et al. PD-1-expressing tumor-infiltrating T cells are a favorable prognostic biomarker in HPV-associated head and neck cancer. Cancer Res. 2013, 73, 128-138. [CrossRef] [PubMed]

47. Weber, J. Immune checkpoint proteins: A new therapeutic paradigm for cancer-preclinical background: CTLA-4 and PD-1 blockade. Semin. Oncol. 2010, 37, 430-439. [CrossRef] [PubMed]

48. Wong, R.M.; Scotland, R.R.; Lau, R.L.; Wang, C.; Korman, A.J.; Kast, W.M.; Weber, J.S. Programmed death-1 blockade enhances expansion and functional capacity of human melanoma antigen-specific CTLs. Int. Immunol. 2007, 19, 1223-1234. [CrossRef] [PubMed]

49. Borkner, L.; Kaiser, A.; van de Kasteele, W.; Andreesen, R.; Mackensen, A.; Haanen, J.B.; Schumacher, T.N.; Blank, C. RNA interference targeting programmed death receptor-1 improves immune functions of tumor-specific T cells. Cancer Immunol. Immunother. 2010, 59, 1173-1183. [CrossRef] [PubMed] 
50. Blank, C.; Kuball, J.; Voelkl, S.; Wiendl, H.; Becker, B.; Walter, B.; Majdic, O.; Gajewski, T.F.; Theobald, M.; Andreesen, R.; et al. Blockade of PD-L1 (B7-H1) augments human tumor-specific T cell responses in vitro. Int. J. Cancer 2006, 119, 317-327. [CrossRef] [PubMed]

51. Postow, M.A.; Callahan, M.K.; Wolchok, J.D. Immune Checkpoint Blockade in Cancer Therapy. J. Clin. Oncol. 2015, 33, 1974-1982. [CrossRef] [PubMed]

52. Melero, I.; Berman, D.M.; Aznar, M.A.; Korman, A.J.; Pérez Gracia, J.L.; Haanen, J. Evolving synergistic combinations of targeted immunotherapies to combat cancer. Nat. Rev. Cancer 2015, 15, 457-472. [CrossRef] [PubMed]

53. Sharma, P.; Allison, J.P. The future of immune checkpoint therapy. Science 2015, 348, 56-61. [CrossRef] [PubMed]

54. Karaki, S.; Anson, M.; Tran, T.; Giusti, D.; Blanc, C.; Oudard, S.; Tartour, E. Is There Still Room for Cancer Vaccines at the Era of Checkpoint Inhibitors. Vaccines 2016, 4, 37. [CrossRef] [PubMed]

55. Ock, C.-Y.; Keam, B.; Kim, S.; Lee, J.-S.; Kim, M.; Kim, T.M.; Jeon, Y.K.; Kim, D.-W.; Chung, D.H.; Heo, D.S. Pan-Cancer Immunogenomic Perspective on the Tumor Microenvironment Based on PD-L1 and CD8 T-Cell Infiltration. Clin. Cancer Res. 2016, 22, 2261-2270. [CrossRef] [PubMed]

56. Binder, D.C.; Engels, B.; Arina, A.; Yu, P.; Slauch, J.M.; Fu, Y.-X.; Karrison, T.; Burnette, B.; Idel, C.; Zhao, M.; et al. Antigen-specific bacterial vaccine combined with anti-PD-L1 rescues dysfunctional endogenous $\mathrm{T}$ cells to reject long-established cancer. Cancer Immunol. Res. 2013, 1, 123-133. [CrossRef] [PubMed]

57. Curran, M.A.; Montalvo, W.; Yagita, H.; Allison, J.P. PD-1 and CTLA-4 combination blockade expands infiltrating $\mathrm{T}$ cells and reduces regulatory $\mathrm{T}$ and myeloid cells within B16 melanoma tumors. Proc. Natl. Acad. Sci. USA 2010, 107, 4275-4280. [CrossRef] [PubMed]

58. Duraiswamy, J.; Kaluza, K.M.; Freeman, G.J.; Coukos, G. Dual blockade of PD-1 and CTLA-4 combined with tumor vaccine effectively restores T-cell rejection function in tumors. Cancer Res. 2013, 73, 3591-3603. [CrossRef] [PubMed]

(C) 2017 by the authors. Licensee MDPI, Basel, Switzerland. This article is an open access article distributed under the terms and conditions of the Creative Commons Attribution (CC BY) license (http:/ / creativecommons.org/licenses/by/4.0/). 